\title{
AUGMENTED REALITY SEBAGAI MEDIA PEMBELAJARAN INTERAKTIF SENI TARI RANTAYA DI ISI SURAKARTA
}

\author{
Taufiqur Rahman ${ }^{1}$, Johan Patar Hutapea ${ }^{2}$, \\ Latifah Azmul Fauzi ${ }^{3}$, Siti Cholifatur Rohmaniah", \\ dan Rendya Adi Kurniawan ${ }^{5}$
}

\author{
${ }^{1}$ Fakultas Seni Rupa dan Desain, Institut Seni Indonesia Surakarta \\ ${ }^{2}$ Fakultas Seni Rupa dan Desain, Institut Seni Indonesia Surakarta \\ ${ }^{3}$ Fakultas Seni Rupa dan Desain, Institut Seni Indonesia Surakarta \\ ${ }^{4}$ Fakultas Seni Rupa dan Desain, Institut Seni Indonesia Surakarta \\ 1taufiqur152@gmail.com, 2hutapeajohan22@gmail.com, \\ 3latifahazfa8@gmail.com, ${ }^{4}$ cholif125@gmail.com \\ 5rendyakurniawan@gmail.com
}

\begin{abstract}
ABSTRAK
Setiap daerah di Nusantara ini memiliki perbedaan tradisi dan budayanya masing-masing, seperti seni tari. Seni tari tradisi Nusantara didalamnya banyak mengandung muatan tentang pendidikan karakter sebagai media transformasi nilai-nilai kehidupan dalam kepribadian seseorang dalam lingkungan masyarakat. Surakarta terdapat tari khas daerah yang sudah menjadi kebanggaan bernama Tari Gaya Surakarta yang merupakan salah satu tari tradisi yang turun-temurun masih menggunakan waton-waton atau patokan-patokan yang telah ditentukan oleh para empu tari terdahulu. Tari Rantaya termasuk Tari Gaya Surakarta yang diajarkan kepada mahasiswa Prodi Seni Tari, Fakultas Seni Pertunjukkan, ISI Surakarta pada semester II, IV, dan VI. Permasalahan dari mahasiswa mengenai Tari Putra Alus ini antara lain, ritme yang sulit, pasangan menari yang kurang mahir, keterbatasan waktu latihan dalam kelas, mahasiswa hanya mengandalkan mahasiswa lain yang hafal dalam pengajaran di dalam kelas, media buku materi yang terbatas, dan kurangnya media penunjang lain sebagai referensi visual. Upaya percepatan dan pengembangan pendidikan ke depan sangat dibutuhkan adanya inovasi dan kreasi pembelajaran yang lebih baik. Augmented Reality (AR) sebagai hasil berupa teknologi yang menggabungkan benda maya dua dimensi dan ataupun tiga dimensi ke dalam sebuah lingkungan nyata tiga dimensi lalu memproyeksikan benda-benda maya tersebut dalam waktu nyata. Tahapan perancangan AR, yaitu : Concept (Pengonsepan), Design (Perancangan), Material Collecting (Pengumpulan Bahan), Assembly (Pembuatan), Testing (Pengujian), dan Distribution (Pendistribusian). Hasil perancangan ini dibagi menjadi tiga karya desain yaitu : desain buku materi Rantaya, desain aplikasi Augmented Reality $(A R)$, dan desain modelling. Teknologi ini sangat membantu pembelajaran Tari Rantaya, mudah pengoperasiannya dan dapat diulang-ulang agar mahasiswa Prodi Seni Tari FSPISI Surakarta dapat melakukan tarian tersebut sehingga materi perkuliahan dapat berjalan lancer. Augmented Reality (AR) dapat menjadi solusi ke depannya, sehingga seni budaya nusantara dapat dipelajari dan dikembangkan agar tetap lestari sekaligus menjaga warisan leluhur agar tidak punah.
\end{abstract}

Kata kunci: augmented reality, Tari Rantaya, media pembelajaran, teknologi informasi.

\section{PENDAHULUAN}

Keberagaman yang kaya akan tradisi dan suku bangsa merupakan ciri dari negara Indonesia. Semakin kuat arus globalisasi di mana semakin muda generasi masih mencari identitas dan tidak tahu banyak tentang makna di balik karya-karya tradisional leluhur warisan yang kita miliki, walaupun di balik semua itu ada norma yang bisa dipelajari dan diterapkan dalam kehidupan. (S.H. Heriwati, dkk, 2019 :1551). Setiap daerahnya memiliki perbedaan tradisi dan budayanya masing- masing. Perbedaan pengaruh budaya dari satu suku bangsa dan suku bangsa lain terjadi karena adanya kontak budaya yang sulit dihindari. Hal itu dinamakan dengan akulturasi, kemudian menciptakan kesenian. Salah satu cabang di bidang kesenian, yakni seni tari. Seni tari ini sendiri, telah banyak menarik minat warga asing untuk mempelajarinya. Potensi dari berupa seni tradisi (folklore), di mana seni tari, cerita rakyat, permainan anak, pantun, budaya lisan, dan yang lainnya walaupun berjumlah banyak sebagian besar mereka tidak terdokumentasi dengan baik, perlu 
dikembangkan dalam hal cerita, presentasi, dan penggunaan media alternatif lainnya. Selain itu, untuk membuat generasi muda menerima cerita seni tradisi diperlukan penyesuaian dan inovasi (Prilosadoso, dkk, 2019:3).

Beberapa pengertian tari, dapat dijelaskan sebagai berikut, seni tari adalah ekspresi jiwa manusia melalui gerak-gerak ritmis dan melodi yang indah (Soepandi, 1994 : 49). Berdasarkan pengertian tersebut dapat diartikan bahwa seni tari sebagai bentuk sikap pengekspresikan diri melalui gerakan-gerakan indah, serta memiliki aturan-aturan (pakem) tertentu seperti gerak, irama, ekspresi bahkan busana, dengan berdasarkan adat budaya. Indonesia pada setiap daerahnya memiliki keragaman seni tari masingmasing. Baik tari tradisi maupun tari kontemporer. Tarian nusantara didalamnya banyak mengandung muatan tentang pendidikan karakter sebagai media transformasi nilai-nilai kehidupan dalam kepribadian seseorang dalam lingkungan masyarakat (Sutedjo dan Prilosadoso, 2016 : 23). Wilayah Surakarta contohnya, terdapat tari khas daerah yang sudah menjadi kebanggaan bernama Tari Gaya Surakarta yang merupakan salah satu tari tradisi di Indonesia. Tradisi adalah tari yang turun temurun dari keraton. Tari tradisi turun-temurun masih menggunakan waton-waton atau patokan-patokan yang telah ditentukan oleh para empu tari terdahulu yang berarti "pantang diubah". Tari tradisi, khususnya tari tradisi gaya Surakarta termasuk tari tradisi keraton. Tarinya dipercaya sebagai yasan delem (ciptaan raja), hal ini masih menjadi kepercayaan bahwa tari tersebut merupakan pusaka kerajaan (Sriyadi, 2013 : 227).

Prodi Seni Tari Fakultas Seni Pertunjukan Institut Seni Indonesia Surakarta menerapkan tari gaya Surakarta ini ke dalam mata kuliah wajib ditempuh oleh mahasiswa prodi tari. Mata kuliah ini terbagi menjadi 5 (lima) kali tempuh semester. Tari Gaya Surakarta terdiri dari 3 (tiga) macam, yakni Putra Alus, Putri dan Gagah (Raksasa/Buto). Tari Putra Alus memiliki ciri intonasi musik yang pelan, gerakan halus, bahkan pada saat gerakan perang juga halus. Sedangkan Tari Putri memiliki ciri khas lebih aktif dan ritme lebih cepat bila dibandingkan dengan Tari Alus. Serta pada Tari Gagah memiliki ciri khas gerakannya lebih lugas, lincah, atraktif dan ritme musik yang berbeda bila dibandingkan kedua tari sebelumnya. Ketiga jenis tari tersebut terdiri atas materi dan praktek. Berikut data hasil survey mengenai tingkat kesulitan dalam Rantaya yang dilakukan pada mahasiswa Prodi Seni Tari, Fakultas Seni Pertunjukan, ISI Surakarta, seperti di bawah ini :
MAHASISWA PRODI SENI TARI

FAKULTAS SENI PERTUNJUKAN ISI SURAKARTA

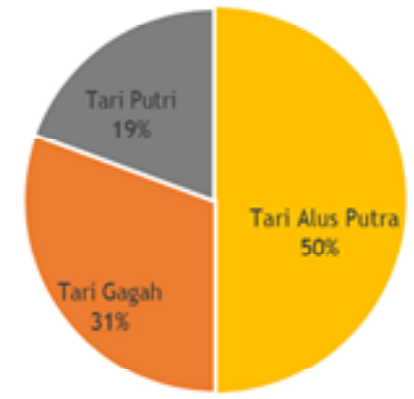

" TariAlus Putra $=$ TariGagah m Tari Putri

Gambar 1. Diagram Hasil Kuesioner Tingkat

Kesulitan Gaya Seni Tari

Sumber : Taufiqur Rahman, 2018

Berdasarkan diagram lingkaran di atas dari hasil survey yang dilakukan pada tahun 2019, mengenai tingkat kesulitan tari gaya Surakarta yang dirasakan oleh mahasiswa Prodi Seni Tari semester II, IV, dan VI. Data tersebut diperoleh dari hasil survey lapangan berupa menjawab beberapa pertanyaan di google form, yang diimple-mentasikan ke dalam diagram tersebut. Diagram tersebut menunjukkan bahwa mahasiswa Prodi Seni Tari ISI Surakarta merasa sulit pada Tari Alus Putra dibandingkan kedua tarian lainnya, yakni sekitar setengahnya dari total keseluruhan mahasiswa. Survey tersebut juga meng-hasilkan data kualitatif, yang merupakan permasalahan yang dialami mahasiswa.

Permasalahan mahasiswa mengenai tari putra alus ini antara lain, ritme yang sulit, pasangan menari yang kurang mahir, keterbatasan waktu latihan dalam kelas. Serta proses latihan di luar jam kelas, mahasiswa hanya mengandalkan maha-siswa lain yang hafal dalam pengajaran di dalam kelas. Selain itu media buku materi yang terbatas. Kurangnya media penunjang lain, seperti video digital sebagai referensi visual. Terbatasnya referensi video digital dikarenakan, adanya hak cipta oleh ISI Surakarta. Hal itu dikarenakan untuk melindungi tarian agar tetap sesuai dengan pakem yang ada. Sebelum memulai praktek menari, perlu memahami olah gerak dasar yang disebut dengan Rantaya. Setiap jenis tari memiliki Rantaya yang berbeda. Namun karena permasalahan proses belajar yang kurang tepat dan efisien, sehingga mempengaruhi mahasiswa tari dalam mempelajari gerak dasar/ Rantaya.

Hasil wawancara dengan Didik Bambang Wahyudi (2019), seorang dosen tari menuturkan Rantaya merupakan rangkaian tari yang tepat untuk 
melatih tubuh kepenarian dan olah rasa bagi penari pemula. Jika sudah memahami Rantaya / dan II, maka penari dapat memahami tarian lainnya dengan baik. Tambahan pendapat lain, bahwa dengan mempelajari tari putra alus, maka akan dengan mudah untuk mempelajari tarian lain, bahkan seperti tari Bali contohnya.

Sistem pendidikan yang dianut ISI Surakarta hanya terpaku pada masukan dari pembimbing yang berlangsung selama jam perkuliahan, serta ruangan yang terbatas, pada hakikatnya kurang dinamis, efektif dan efesien serta muaranya berhenti di tempat. Hal ini menjadi keluhan bagi kebanyakan mahasiswa tari. Upaya percepatan dan pengembangan pendidikan ke depan sangat dibutuhkan adanya inovasi dan kreasi pembelajaran yang lebih baik. Perkembangan teknologi yang semakin pesat, maka proses pendidikan pun perlu menerapkan teknologi yang terkini. Perlu adanya media yang baru, dan promosi yang lebih agar masyarakat tertarik khususnya untuk kalangan remaja yang memiliki tugas untuk mengemban pelestarian nilai-nilai tradisi (Guizar dan Panindias 2019: 77). Teknologi yang tepat dalam proses pembelajaran tari gaya Surakarta ialah menggunakan teknologi Argumented Reality (AR).

Augmented Reality (AR) merupakan salah satu bagian dari Virtual Environment (VE) atau yang biasa dikenal dengan Virtual Reality (VR). AR memberikan gambaran kepada pengguna tentang penggabungan dunia nyata dengan dunia maya dilihat dari tempat yang sama. AR memiliki tiga karakteristik yaitu bersifat interaktif (meningkatkan interaksi dan persepsi pengguna dengan dunia nyata), menurut waktu nyata (real time) dan berbentuk 3Dimensi penetapan standar kompetensi bagi setiap pengetahuan yang bersifat edukatif maupun populer. Hal ini untuk memberikan stimulus terhadap penetapan (Triyono, 2017: 807).

Adanya pengadaan AR pada proses pembelajaran tari gaya Surakarta ini terutama bagian Rantaya, dapat membantu mahasiswa tari dalam proses latihan di luar jam perkuliahan. Penerapannya dengan diadakannya buku materi berteknologi AR, merupakan inovasi yang praktis dan efisien tanpa peduli ruang, waktu dan pakem. Buku materi ini disusun dengan berkerjasama dengan dosen Prodi Seni Tari, FSP, ISI Surakarta, yang sesuai dengan kurikulum mata kuliah di prodi tersebut.

Buku materi ini sebagai penunjang proses pembelajaran mahasiswa di luar jam perkuliahan. Teori berfungsi sebagai modal awal persiapan mahasiswa tari pemula dalam melakukan praktek Tari Putra Alus
Gaya Surakarta. Buku materi ini terdiri dari teori dan praktek rantaya. Cara penggunaan buku materi Augmented Reality (AR), pada bagian materi praktek para mahasiswa menginstall aplikasi yang tertera di buku materi melalui smartphone. Kemudian mengscan bagian marker gerakan Rantaya yang diinginkan, maka akan muncul berupa pop up animasi 3D modelling, sehingga dapat dilihat 360 derajat secara detail pada setiap gerakan dasar Tari Gaya Surakarta, sehingga mahasiswa dapat belajar sendiri dari sumber yang valid.

\section{LANDASAN TEORI}

\section{Media Permainan dalam Perkembangan Manusia}

Jean Piaget telah membagi perkembangan kognitif menjadi 4 (empat) stadium utama dan beberapa sub-stadium. Perkembangan kognitif pada anak usia prasekolah berada pada stadium pra-operasional dan akan terus berlanjut sampai usia 7 tahun (Suparno, 2006: 11). Pada usia ini anak mulai memiliki kemampuan untuk merencanakan, berusaha mencapai sesuatu, dan keteguhan dalam pencapaian tugas. Anak di usia ini memiliki motivasi untuk belajar dan berusaha untuk tampil baik dan melaksanakan kewajibannya. Aktifitas utama dalam usia ini adalah bermain yang memiliki unsur tujuan di dalamnya. Karakteristik permainan pada usia ini adalah dramatisasi atau bermain peran. Mereka senang sekali memakai kostum dan berpura-pura menjadi orang lain yang lebih dewasa. Namun juga harus diperhatikan agar kebiasaan dramatisasi ini tidak terus berlanjut sampai dewasa karena dapat mengakibatkan seseorang terbiasa untuk merepresentasikan dirinya dalam sosok yang berbeda.

Perkembangan kehidupan manusia telah diawali sejak individu masih dalam kandungan sampai menginjak usia dewasa. Tahapan-tahapan tersebut saling berkaitan dalam satu kesatuan yang utuh. Tahapan perkembangan individu anak diawali dari refleks kemudian perkembangan susunan syaraf pusat dan berkembanganya fungsi lain, antara lain: motorik, emosi, inteligensia dan sosial. Pembatasan mengenai usia anak banyak ahli yang memberi penjelasan yang bervariasi. Menurut Sharmi Mahdi (1983) dalam Sunarmi (2000: 12), yang dimaksud usia anak adalah usia 1 (satu) sampai dengan usia 12 (dua belas) tahun. Tahap tersebut dibagi lagi menjadi dua yaitu: (1) Usia balita yaitu usia satu tahun sampai usia lima tahun; (2) Usia sekolah yaitu usia enam sampai dengan usia dua belas tahun. 
Permainan tradisional sendiri memiliki banyak manfaat untuk mengembangkan kepribadian anak karena cara bermain yang selalu berkelompok menjadikan anak belajar. Banyak pula permainan anak-anak yang dibuat sendiri, dengan bahan baku yang ada di sekitar dapat menjadikan anak berfikir kreatif dan di Indonesia memiliki ragam permainan tradisional yang dapat dicoba (Fikratur-rosyida dan Taufik Murtono, 2018: 85).

\section{Media Pembelajaran Untuk Siswa Sekolah Dasar}

Perancangan media pembelajaran ini berupa media sebagai alat, perantara dimana tujuannya memudahkan manusia untuk menyampaikan sesuatu. Media merupakan sarana penyampaian pesan dari komuni-kator kepada komunikan. (Permana dan Ana Rosmiati, 2018 : 3). Mediapun dapat dikatakan komunikasi antar dua orang atau lebih yang saling berinteraksi agar apa yang disampaikan salah satu pihak dapat dimengerti oleh pihak yang lainnya. Media bisa dikatakan sebagai penghantar untuk menyampaikan maksud dari seseorang ke orang lain agar dapat dipahami dengan mudah. Pelatihan yang mencoba diterapkan bagi peserta akan menitikberatkan aspek pengajaran sebagai unsur pokok dengan penggunaan aspek media pembelajaran yang tepat (Prilosadoso, dkk. 2017: 105). Penjelasan dari pengertian media bisa dikatakan pembentuk kesadaran sosial yang pada akhirnya menentukan persepsi orang terhadap dunia dan masyrakat tempat mereka hidup. Media pembelajaran khususnya untuk anak, artinya anak sebagai pribadi yang masih dalam proes beradaptasi dan banyak belajar dari lingkungan di luar dirinya sebagaimana lingkungannya (Lilis, 2014: 32).

Pengajaran akan lebih efektif apabila objek dan kejadian yang menjadi bahan pengajaran dapat divisualisasikan secara realistik menyerupai keadaan yang sebenarnya, namun tidaklah berarti bahwa media harus selalu menyerupai keadaan sebenarnya. Sebagai contoh adalah model. Model sekalipun merupakan gambaran nyata dari objek dalam bentuk tiga dimensi tidak dapat dikatakan realistik sepenuhnya. Sungguhpun demikian model sebagai media pengajaran dapat memberi makna terhadap isi pesan dari keadaan yang sebenarnya (Sudjana dan Rivai, 2009: 9). Secara singkat ada yang mendefinisikan media adalah sesuatu perangkat penyalur yang didapat menyalurkan informasi dari sumber ke penerima sumber. Sedangkan menurut Uno (2008: 2) mengemukakan bahwa hakikat pembelajaran adalah perencanaan atau perancangan (desain) sebagai upaya untuk membelajarkan siswa. Disimpulkan dari pengertian di atas media pembelajaran adalah suatu alat atau sarana menyalurkan informasi untuk mengedukasi seseorang dalam memahami suatu informasi yang disampaikan. Dengan menggunakan media pembelajaran yang tepat akan mempermudah anak untuk menangkap pengetahuan yang baru dalam belajar mereka.

\section{METODE PERANCANGAN AUGMENTED REALITY TARI RANTAYA}

Metode dalam pelaksanaaan kegiatan pengenalan ini mengutamakan keaktifan antara peserta dan mentor ditunjang dengan penggunaan media dan model pelatihan yang efektif dan efisien. Sebelum masuk tahap metode, tahapan pemilihan konsep dapat dipahami sebagai dasar pemikiran yang strategis untuk mencapai satu tujuan. Konsep dalam bidang desain adalah dasar pemikiran strategis yang akan digunakan sebagai landasan pengambilan keputusan. (Astuti dan Ana Rosmiati, 2018: 63). Media Pembelajaran memiliki peranan yang sangat penting pada proses perancangan inovasi teknologi ini. Metode pengembangan/perancangan yang penulis gunakan dalam penelitian ini adalah metode Multimedia Development Life Cycle (MDLC) versi LutherSutopo. Metode pengembangan multimedia menurut Sutopo dalam Setiawan, dkk (2016: 39), yang berpendapat bahwa metode pengembangan multimedia terdiri dari enam tahapan, yaitu tahapan concept, design, material collecting, assembly, testing, dan distribution, di mana enam tahapan pengembangan multimedia tersebut dapat dilihat sebagai berikut.

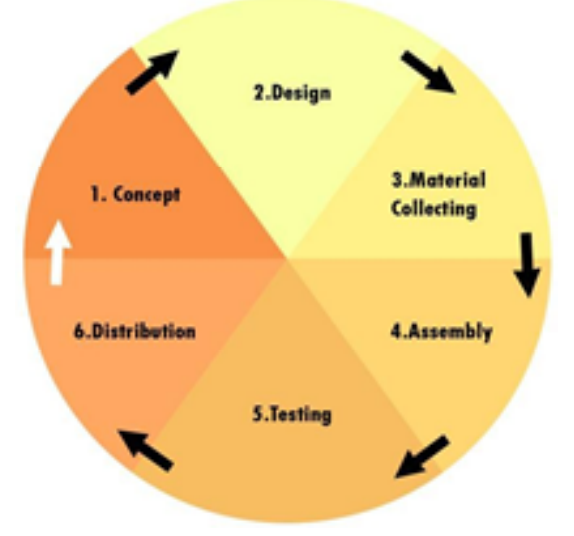

Gambar 2. Multimedia Development Life Cycle (MDLC)

Sumber: Sutopo dalam Setiawan, dkk, 2016 
Tahapan-tahapan tersebut dapat dijelaskan dalam keterangan di bawah ini :

1. Concept (Pengonsepan)

Menentukan tujuan dan manfaat buku materi berbasis $A R$ sebagai media pembelajaran seni tari, serta mendes-kripsikan konsep buku materi berbasis teknologi AR yang akan dibangun.

2. Design (Perancangan)

Pada tahap ini pembuatan spesifikasi mengenai perancangan buku materi berbasis teknologi AR, gaya, tampilan, dan kebutuhan material / bahan untuk program. Desain yang akan dibuat mengunakan desain interface dari tampilan menu aplikasi.

3. Material Collecting (Pengumpulan Bahan) Tahap ini adalah tahap pengumpulan bahan yang sesuai dengan kebutuhan yang dikerjakan. Bahanbahan tersebut antara lain software 3D, camera 360 , model penari, literasi, dan lain-lain.

4. Assembly (Pembuatan)

Tahap pembuatan semua objek atau bahan multimedia. Pembuatan 3D Modelling penari, animasi gerakan dasar/Rantaya, Augmented Reality, Marker pada buku materi, serta pembuatan aplikasi untuk scan dan penerapannya pada buku materi.

5. Testing (Pengujian)

Tahap testing (pengujian) dilakukan setelah menyelesaikan tahap pembuatan (assembly). Proses ini dilakukan dengan tujuan menguji seluruh komponen objek atau bahan agar dapat berfungsi sesuai konsep dan rancangan. Tahap selanjutnya dilihat apakah ada kesalahan atau tidak atau disebut juga sebagai tahap pengujian alpha (alpha test) yang pengujiannya dilakukan oleh pembuat atau lingkungan pembuatnya sendiri. Setelah lolos dari pengujian alpha, kemudian pengujian beta (beta test) yang melibatkan pengguna utama yaitu mahasiswa seni tari.

6. Distribution (Pendistribusian)

Tahap awal, buku materi ini akan didistribusikan untuk mahasiswa semester satu Prodi Seni Tari FSP ISI Surakarta. Tahapan perancangan dapat dijelaskan lebih detil dengan bagan alir di bawah ini :
Tahop Concept (Pengonsepan)

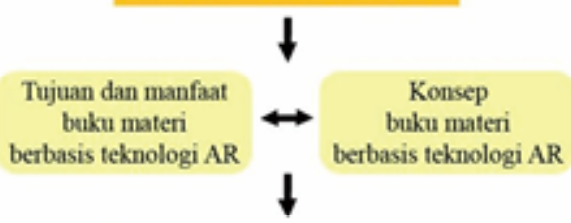

Tahap Design (perantangan)

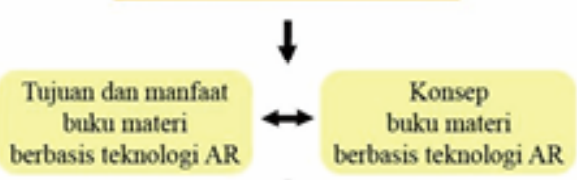

$\downarrow$

Material collecting (pengumpulan bahan)

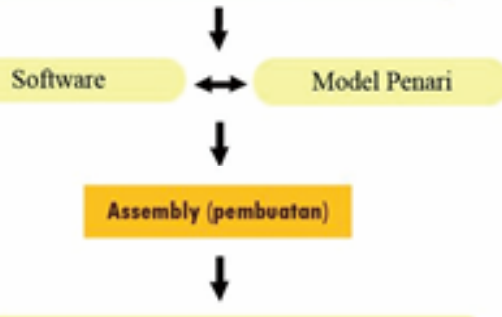

Pembuatan buku materi berbasis teknologi AR
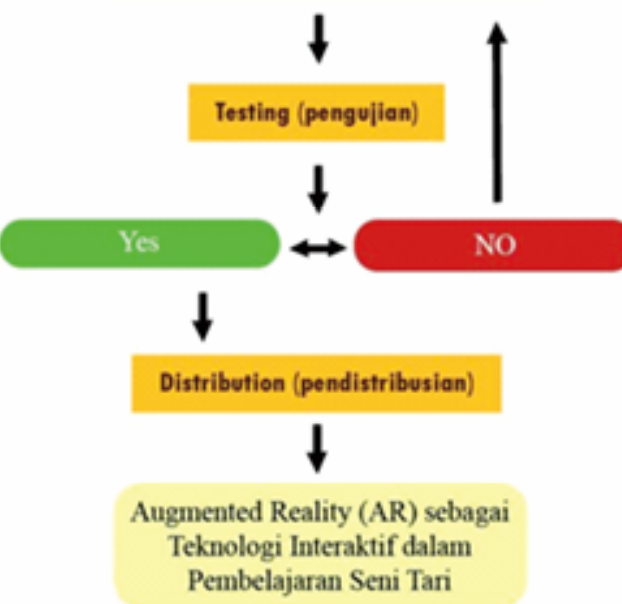

Gambar 3. Metode Pelaksanaan Program Kegiatan Sumber : Diolah Dari Berbagai Sumber, 2019

\section{ANALISIS FUNGSIONAL DAN CARA KERJA}

Tari Alus Gaya Surakarta merupakan mata kuliah wajib untuk Prodi Tari FSP ISI Surakarta, dimana mahasiswa prodi tersebut banyak mengalami kesulitan dalam proses pembelajaran. Hal yang paling umum karena terbatasnya media, akibat adanya hak cipta oleh ISI Surakarta, dikarenakan untuk melindungi tarian agar tetap sesuai dengan pakem yang ada. Melihat dari persoalan di atas, menghasilkan solusi buku materi 
berbasis Augmented Reality, di mana teknologi tersebut tepat, dalam pembuatan buku materi proses pembelajaran tari gaya Surakarta.

Buku materi ini terdiri dari teori dan praktek Rantaya. Teori berfungsi sebagai modal awal persiapan mahasiswa tari pemula dalam melakukan praktek tari putra alus gaya Surakarta. Bagian teori berisi sejarah tari gaya Surakarta, materi tari alus putra, pembagian Rantaya 1 dan 2. Buku materi ini diperlukan oleh Prodi Tari khususnya ISI Surakarta, dalam proses pembelajaran mata kuliah, bahkan penggunaannya bisa dilakukan pada luar jam mata kuliah. Peralatan yang digunakan untuk menggunakan buku materi berbasis AR ini juga mudah, yakni smartphone yang sudah menginstal aplikasi khusus. Aplikasi ini mendeteksi marker menggunakan kamera smartphone, jika kamera dapat menandai dan mengenali pola marker pada buku materi, webcam akan menampilkan obyek animasi 3D Modelling pada layer smartphone mahasiswa. AR animasi 3D Modelling obyek animasi tersebut, membuat mahasiswa tari dapat berinteraksi, yakni gerakan Rantaya Tari Alus Putra secara lebih detail. Menjadi suatu inovasi yang baru dan buku materi pembelajaran yang sangat bermanfaat, apabila dibandingkan dengan video pembelajaran yang hanya menampilkan visual $2 \mathrm{D}$.

\section{HASIL DAN PEMBAHASAN}

Perancangan merupakan salah satu unsur penting dalam pembuatan suatu karya. Dalam pembuatan karya ini, dibagi menjadi tiga karya desain yaitu desain buku materi Rantaya, desain aplikasi Augmented Reality (AR), dan desain modelling. Untuk lebih jelasnya akan dipaparkan lebih detil hasil dari perancangannya, seperti di bawah ini :

\section{Buku Materi}

Buku materi menjadi komponen utama dalam media pembelajaran interaktif augmented reality pada Prodi Seni Tari di ISI Surakarta. Buku materi digunakan dalam bidang pembelajaran di lingkup Prodi Seni Tari. Terciptanya buku ini untuk menjawab permasalahan yang dialami mahasiswa, mengenai mata kuliah tari gaya Surakarta, khususnya Rantaya tari alus putra. Buku materi ini berbasis teknologi $A R$, yakni memunculkan obyek 3D mengenai Rantaya. Penggunaan AR membantu mahasiswa seni tari melihat objek gambar dalam buku materi menjadi lebih interaktif.

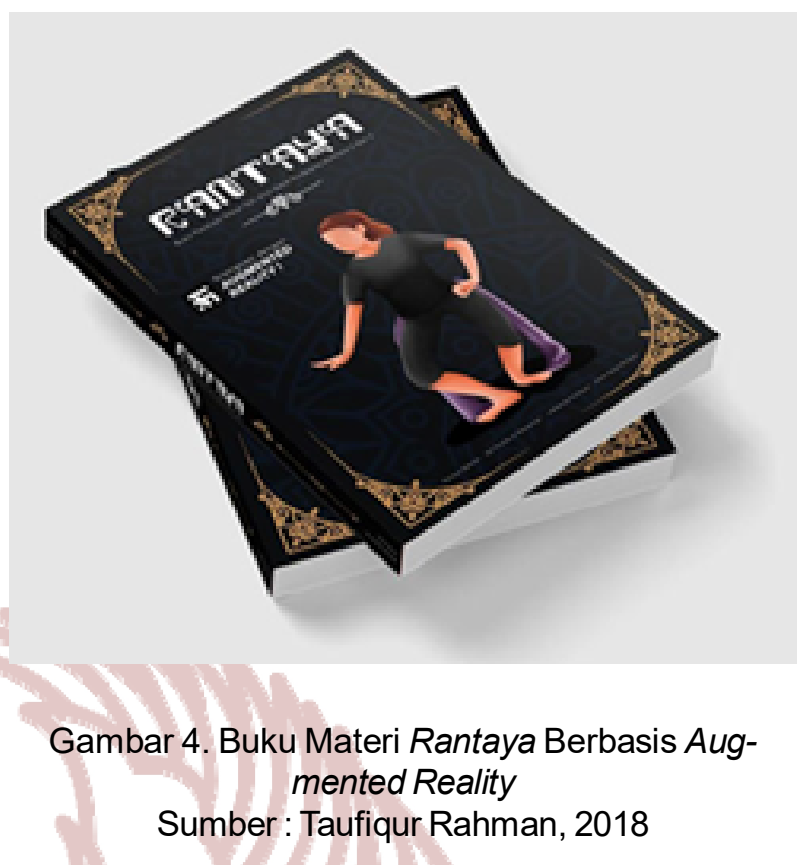

\section{3D Modelling}

Tahapan ini sebagai proses untuk menciptakan objek 3D yang ingin dituangkan dalam bentuk visual nyata, baik secara bentuk, tekstur, dan ukuran objeknya. Pengertian lainnya adalah sebuah teknik dalam komputer grafis untuk memproduksi representasi digital dari suatu objek dalam tiga dimensi (baik benda mati maupun hidup). 3D Modelling menjadi proses awal dalam pembuatan AR. Obyek 3D tersebut berupa uraian gerakan dari Rantaya Alus. Proses pembuatannya obyek Rantaya, menggunakan acuan foto penari, kemudian diimport ke aplikasi. Banyak beberapa software untuk membuat obyek 3D, seperti 3DS Max, Blender, Mushroom, dan lain-lain. Melihat keunggulan berbagai software tersebut, dipilihlah Blender sebagai aplikasi dalam pembuatan 3D modelling Rantaya. Langkah selanjutnya, pada aplikasi blender, membuat obyek dasar bervolume seperti kubus, bola, dan lain-lain. Obyek dasar bervolume memiliki titik fartage, yang kemudian diedit sesuai dengan bentuk diinginkan.

\section{Animasi}

Animasi berasal dari bahasa Inggris yaitu animate yang artinya menghidupkan, memberi jiwa dan mengerakan benda mati. Animasi merupakan proses membuat objek yang asalnya objek mati, kemudian disusun dalam posisi yang berbeda seolah menjadi hidup. Di dalam animasi ada dua objek penting, yaitu objek atau gambar dan alur gerak. Proses pembuatan animasi bermula dari $3 D$ Modelling untuk 
menghasilkan objek digital yang dapat digerakan secara leluasa, pembuatannya menjadi salah satu proses yang dibutuhkan dalam karakter animasi dan Augmented Reality.

\section{Augmented Reality (AR)}

Augmented Reality atau dalam bahasa Indonesia Realitas tertambah dan dikenal dengan singkatan bahasa Inggrisnya AR. Pengertian dari Augmented Reality adalah teknologi yang menggabungkan benda maya dua dimensi dan ataupun tiga dimensi ke dalam sebuah lingkungan nyata tiga dimensi lalu memproyeksikan benda-benda maya tersebut dalam waktu nyata.

AR menjadi solusi untuk menjawab persoalan di Prodi Seni Tari, dengan menggunakan teknologi yang menggabungkan benda maya tiga dimensi ke dalam sebuah lingkungan nyata. Cara kerja AR yakni mendeteksi marker Rantaya pada buku materi. Prinsip kerjanya adalah kamera smartphone yang mendeteksi marker. Marker merupakan visual tag yang dimasukkan kedalam aplikasi khusus yang telah dibuat.

Kamera tersebut mendeteksi atau mengenali pola marker. Selanjutnya webcam akan melakukan perhitungan apakah marker sesuai dengan database yang dimiliki. Apabila database tidak sesuai, maka informasi marker tidak akan diolah, tetapi bila sesuai maka informasi marker akan digunakan untuk merender dan menampilkan animasi 3D modelling dari Rantaya yang telah dibuat sebelumnya. Aplikasi tersebut saat dilakukan pemindaian maka akan muncul obyek animasi modelling gerakan Rantaya. Obyek animasi tersebut, membuat mahasiswa tari dapat berinteraksi, yakni dapat melihat gerakan Rantaya secara lebih detail.

\section{Aplikasi}

Aplikasi yang dibangun merupakan sebuah aplikasi yang digunakan untuk membaca marker yang terdapat di buku materi. Aplikasi ini akan menampilkan Augmented Reality dari obyek 3D gerakan rantaya. Cara kerjanya adalah mendeteksi marker menggunakan kamera smartphone, jika kamera dapat menandai dan mengenali pola marker pada buku materi, webcam akan menampilkan obyek animasi $3 D$ Modelling pada layer smartphone mahasiswa.

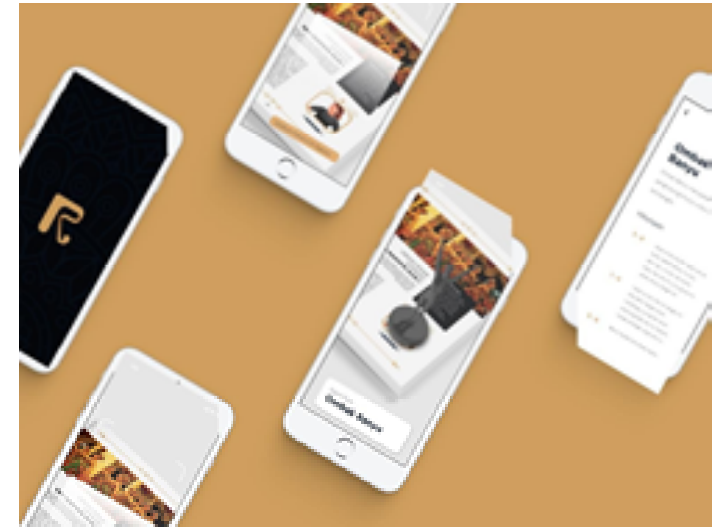

Gambar 5. Mockup Aplikasi "Rantaya" Sumber : Taufiqur Rahman, 2018

Software yang diperlukan dalam proses pembuatan aplikasi untuk scan AR Rantaya ialah Unity 3D dan Vuforia SDK. Software Unity 3D digunakan untuk membuat animasi 3D Modelling dapat berfungsi dalam AR. Sedangkan Vuforia SDK merupakan software tambahan, berfungsi untuk merender hasil projek di Unity 3D.

\section{KESIMPULAN}

Perancangan merupakan salah satu unsur penting dalam pembuatan suatu karya, di mana hasil perancangan ini dapat dibagi menjadi tiga karya desain yaitu desain buku materi Rantaya, desain aplikasi Augmented Reality (AR), dan desain modelling. Augmented Reality (AR) sebagai hasil berupa teknologi yang menggabungkan benda maya dua dimensi dan ataupun tiga dimensi ke dalam sebuah lingkungan nyata tiga dimensi lalu memproyeksikan benda-benda maya tersebut dalam waktu nyata. Media Augmented Reality (AR) sebagai menjadi solusi untuk menjawab persoalan di Prodi Seni Tari, dengan menggunakan teknologi yang menggabungkan benda maya tiga dimensi ke dalam sebuah lingkungan nyata melalui cara kerja melalui AR dengan mendeteksi marker Rantaya pada buku materi lewat aplikasi.

Aplikasi yang dibangun merupakan sebuah aplikasi yang digunakan untuk membaca marker yang terdapat di buku materi. Aplikasi ini akan menampilkan Augmented Reality dari obyek 3D gerakan Rantaya. Cara kerjanya adalah mendeteksi marker menggunakan kamera smartphone, jika kamera dapat menandai dan mengenali pola marker pada buku materi, webcam akan menampilkan obyek animasi 3D Modelling pada layer smartphone mahasiswa yang sedang mempelajari Tari Rantaya. Aplikasi tersebut 
saat dilakukan pemindaian maka akan muncul obyek animasi modelling gerakan Rantaya. Obyek animasi tersebut, membuat mahasiswa tari dapat berinteraksi, yakni dapat melihat gerakan Rantaya secara lebih detail.

Teknologi ini sangat membantu pembelajaran Tari Rantaya, selain dapat dilakukan dimana dan kapan saja, AR ini juga memudahkan pengoperasiannya dan dapat diulang-ulang agar mahasiswa Prodi Seni Tari FSP ISI Surakarta dapat melakukan tarian tersebut sehingga materi perkuliahan dapat berjalan lancer. Selain itu, dengan teknologi ini, banyak seni tari lainnya yang memiliki tingkat kesulitan yang tinggi, dosen pengampu yang terbatas, serta media dan metode pembelajaran yang belum maksimal, maka penggunaan Augmented Reality (AR) dapat menjadi solusi ke depannya, sehingga seni budaya nusantara dapat dipelajari dan dikembangkan agar tetap lestari sekaligus menjaga warisan leluhur agar tidak punah

\section{DAFTAR PUSTAKA}

Astuti, Tias Puji, dan Ana Rosmiati. 2018. Gaya Desain Cover Buku Karya Djenar MaesaAyu Tahun 2016. TEXTURE : Art \& Culture Journal. Vol 2, No 1 (2019) ISSN Cetak (Print) 2655-6766 ISSN Online 2655-6758. hal. 63.

Fikraturrosyida, Vikhi, dan Taufik Murtono. 2018. Perancangan Ambient Media Sebagai Sarana Promosi Permainan Tradisional Komunitas Anak Bawang Surakarta, TEXTURE : Art \& Culture Journal. Vol 1, No 1 (2018) ISSN Cetak (Print) 2655-6766 ISSN Online 2655-6758. hal. 85.

Guizar, Vicky Tito dan Asmoro Nurhadi Panindias. 2019. Media Promosi Edukasi Sejarah Melalui Perancangan Karakter Visual Singo Ulung Bondowoso. TEXTURE : Art \& Culture Journal. Vol 2, No 1 (2019) ISSN Cetak (Print) 2655-6766 ISSN Online 2655-6758. hal. 77 .

Hamzah B. Uno, 2008, Perencanaan Pembelajaran. Jakarta: Bumi Aksara, hlm. 2. Prilosadoso, Basnendar Herry, dkk. 2017.

Jurnal Batoboh, Jurnal Pengabdian Pada Masyarakat. ISSN: 2548 - 5458 Volume 2, Nomor 2, Oktober 2017. Institut Seni Indonesia (ISI) Padangpanjang. hal. 105
Lilis Dede. 2014. Media Anak Indonesia: Representasi Idola Anak dalam Majalah Anak-Anak. Jakarta : Yayasan Pustaka Obor Indonesia.

Nana Sudjana dan Ahmad Rivai. 2009. Media Pengajaran. Bandung, Sinar Baru Algensindo, hal 9.

Paul Suparno, 2006. Perkembangan Kognitif Jean Piaget, Yogyakarta: Kanisius, Cet I, hal.11

Permana, Anintya Wanda, dan Ana Rosmiati. 2018. Iklan Aqua "Versi Narji Dan Sandy Sandoro". PENDHAPA, Jurnal Ilmiah Pengkajian dan Penciptaan Seni Rupa dan Desai Volume 9 No.1 Juni 2018. ISSN 2086-8138 (print). hal. 3.

Prilosadoso, Basnendar Herry, dkk. 2019. Cartoon Character in Animation Media for Preserving Folklore Traditional Art in Surakarta, SEWORD FRESSH 2019, April 27, Surakarta, Indonesia, EAI DOI 10.4108/ eai.27-4-2019.2286814, p. 3.

S. H. Heriwati, B. H. Prilosadoso, B. Pujiono, Suwondo, and A. N. Panindias, 2019. 3D Puppets Animation For Encouraging Character Education and Culture Preservation In Surakarta, Int. J. Eng. Adv. Technol., vol. 9, no. 1, 2019. p.1551.

Setiawan, Mudianto, 2016, Aplikasi Pembelajaran Interaktif Berbasis Multimedia Untuk Sekolah Dasar (Study Kasus: SD Negeri 1 Bitung, Kelas VI), Vol 5.4 No.4. ISSN:23018402.E-Journal Teknik Elektro dan Komputer

Soepandi, Atik, 1994, Ragam Cipta Mengenal Seni Pertunjukan Jawa Barat. Bandung : CV. Media.

Sriyadi, 2013, Tari Tradisi Gaya Surakarta. Surakarta : Greget Jurnal Pengetahuan Penciptaan Seni Tari.

Sunarmi. 2000. Alat Permainan Tradisional untukAnak yang Bersifat Kompetitif di Karanganyar Ditinjau dari Aspek Ergonomi, Surakarta : STSI Surakarta, hal. 12 
Sutedjo, Agus dan Basnendar Herry Prilosadoso, 2016, Perancangan Desain Permainan Materi Pendidikan Anak Usia Dini Berbasis Wayang Beber, Acintya: Jurnal Penelitian Seni Budaya, Vol. 8 No. 1, Juni 2016. ISSN Online : 2655-5247 ISSN Cetak : 2085-2444. hal. 23.
Triyono, Joko, 2017, Argumented Reality (AR) Sebagai Teknologi Interaktif dalam Pengenalan Benda Cagar Budaya Kepada Masyarakat, Jurnal Simetris. Vol. 8. No. 2 tahun 2017. Teknik Informatika.

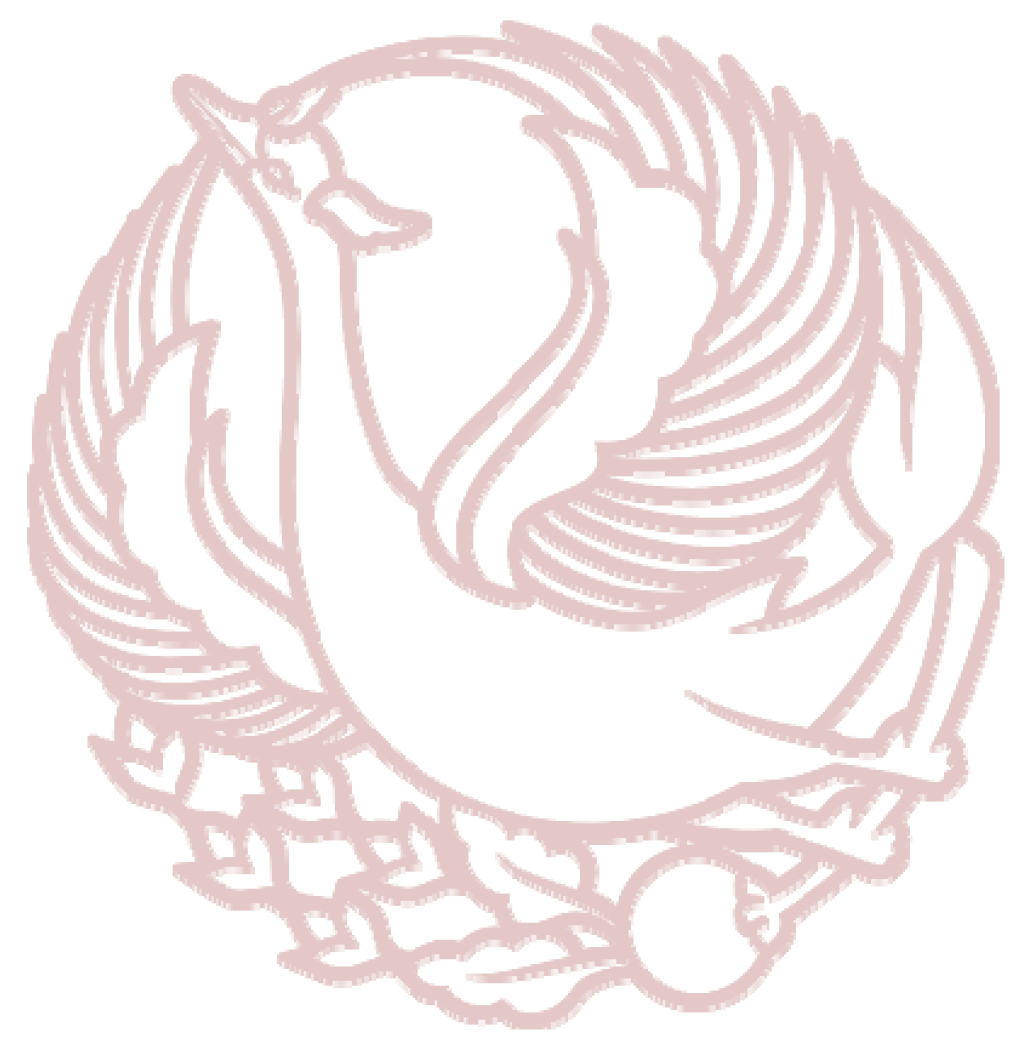

